\author{
ADVANCED INTERNATIONAL JOURNAL OF \\ BUSINESS, ENTREPRENEURSHIP AND SMES \\ (AIJBES) \\ WWW.aijbes.com
}

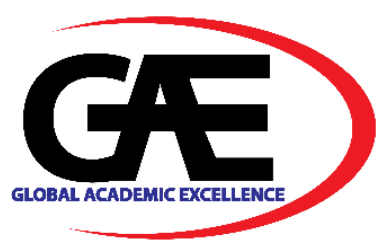

\title{
THE INFLUENCE OF FINANCIAL LITERACY ON BANDUNG GENERATION $Z$ CONSUMERS IMPULSIVE BUYING BEHAVIOR WITH SELF-CONTROL AS MEDIATING VARIABLE
}

\author{
Maximilla Febriana Ayuningtyas ${ }^{1 *}$, Atika Irawan ${ }^{2}$ \\ 1 School of Business and Management, Institut Teknologi Bandung \\ Email: maximilla_febriana@sbm-itb.ac.id \\ 2 School of Business and Management, Institut Teknologi Bandung \\ Email: atika.irawan@sbm-itb.ac.id \\ * Corresponding Author
}

\section{Article Info:}

Article history:

Received date: 08.06.2021

Revised date: 30.06 .2021

Accepted date: 04.08.2021

Published date: 02.09.2021

\section{To cite this document:}

Ayuningtyas, M. F., \& Irawan, A. (2021). The Influence of Financial Literacy on Bandung Generation Z Consumers Impulsive Buying Behavior with Self-Control as Mediating Variable. Advanced International Journal of Business, Entrepreneurship and SMEs, 3 (9), 155-171.

DOI: 10.35631/AIJBES.39012.

This work is licensed under CC BY 4.0

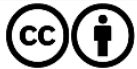

\begin{abstract}
:
The development of information technology in the industrial era 4.0 has affected various aspects of life, including the financial sector by promoting digital payment. The ability to manage finances well is needed in dealing with this situation. Addressing this phenomenon, Indonesian citizens, especially Generation $\mathrm{Z}$ who are considered full of confidence, enthusiasm, and risk-taker are also required to have a comparable readiness to avoid unwanted things like falling into impulsive buying behavior. The objective of this research is to examine: (1) the influence of financial literacy on consumers' impulsive buying behavior; (2) the influence of financial literacy on self-control; and (3) the influence of financial literacy on consumers' impulsive buying behavior with self-control as mediating variable. This study is comparative causal research with a quantitative approach. The object for this study is Generation $\mathrm{Z}$ who are individuals aged 17-24 years and who stayed in Bandung, Indonesia, as Bandung is one of the favorite destinations city in Indonesia to pursue higher studies. The sampling method the author used is convenience and purposive sampling. While the data collection method is through a survey using a questionnaire. The author collecting a total of 422 samples. The data analysis technique used is descriptive statistics, inferential analysis, and path analysis. The findings of this study revealed that: (1) financial literacy has a negative and significant effect on consumers impulsive buying behavior; (2) financial literacy has a positive and significant effect on self-control; and (3) self-control is able to mediate the effect of financial literacy on consumers impulsive buying behavior.
\end{abstract}

Keywords:

Financial Literacy, Impulsive Buying Behavior, Self-Control 


\section{Introduction}

Individuals around the world face financial decisions every day. With the continuous development of information technology in this industry 4.0 era, financial information becomes more abundant than ever. Society is expected to become more tech savvy considering that almost every aspect of life is impacted by it, including the financial sectors. Financial sectors nowadays offer many appealing financial products to meet the society's needs. At the same time, consumers must find their bearings in a market marked by a growing complexity which requires both a firm grasp of increasingly sophisticated products and the ability to determine the quality (Stolper \& Walter, 2017). This market growth goes hand in hand with the increase of complex individual needs that reflects on the increasing personal responsibility, prosperity, life expectancy, indebtedness, and the number of owner-managed enterprises.

Reported by Indonesia CNBC (2020) in Ipsos Marketing Summit 2020: Indonesia, In Indonesia, the trend of mobile payments has grown to promote a cashless society during the previous five years. As a result, society feels safer, more comfortable, and confident in using digital payments. People are prone to make wrong decisions and get lost financially because of the many financial products and conveniences they offer. To inhibit this situation, people need to be equipped with knowledge in finance which could be reflected in their financial literacy level in facing this era. Conceptually, financial literacy refers to skills and can be measured by the percentage correct on a knowledge test where each question has a right answer (Fernandes et al., 2014).

The buying behaviour of each consumer can be different because consumers behaviour changes according to the influence factors. There are some psychological elements which are responsible for impulsive buying behaviour, such as emotions, addiction, stress, age, gender, income, and culture. Individuals, who have no control on a budget, have a higher potential to fall into impulsive shopping that is done without prior thought and planning but afterwards regrets doing so. Impulsive buying spoils budget and divert funds to none or less utility (Choudhary, 2014).

With advances in technology, Generation $\mathrm{Z}$ tends to be more adaptive and flexible in keeping up with technological developments. This is also supported by a variety of modern living facilities, bigger opportunity to access e-commerce, the development of shopping centers, ease of transportation facility, and easy-to-access mass media so that information will be conveyed more quickly (Ridhayani \& Johan, 2020). The increasing individual needs and complex financial products require each individual to manage their finances properly. Therefore, every individual is required to have good financial literacy to be able to manage and determine attitudes on limited resources effectively and efficiently for the welfare of his life. The application of knowledge about financial literacy can be combined with self-control as it can affect an individual's behaviour to be more selective in consuming goods and services.

Self-control can be defined as the ability of individuals to hold back or direct themselves towards the better when faced with the temptations. Whereas control in financial management is an activity that encourages someone to make savings by reducing impulsive purchase (Efendi et al., 2019). In the current era of globalization, implementing self-control becomes more challenging, including for youth. Provided with many choices of financial products, services, and markets, the youth are more likely to bear the greater financial risk of their parents in the future. 
Volume 3 Issue 9 (September 2021) PP. 155-171

DOI 10.35631/AIJBES.39012

The level of financial literacy is largely influenced by the demographics of these individuals. Generation $\mathrm{Z}$ is the generation born between 1997-2012 and is considered as a generation full of confidence, expressiveness, freedom, enthusiasm and challenge, which this characteristic is completely different from the previous generation. Generation $\mathrm{Z}$ grew up with the birth of computers and the Internet, so it can be said that they have the natural wisdom and skills to use new technologies. This generation are considered to be more willing to take risks in decision making, but at the same time, this could make them to be more vulnerable in terms of impulsive behaviour and become more tempted to make an unnecessary purchase. This generation is accustomed to products that are always up-to-date and cares more about holidays and often spend time in expensive cafes and even buy designer clothes than to meet their basic living needs. In line with the advancement of technology, this generation are considered to be more willing to take risks in decision making, but at the same time, this could make them to be more vulnerable in terms of impulsive behaviour and become more tempted to make an unnecessary purchase.

Meanwhile, people have to make tough financial decisions in today's challenging financial environment which affects their behaviour. Individual's emotional state drives them to consume goods and services irrationally. Supported by the existence of online shopping and shopping centres that scattered everywhere, provide the ease of access for consumers in buying products. This phenomenon tends to encourage young people and adolescents to make an impulsive purchase. Without having adequate financial literacy, individuals tend to be unable to make the right decisions about how to manage finances so that many consumers are often tempted to buy many things without considering their financial conditions.

Ability to manage money can be an indicator of financial literacy level. Low financial literacy, which is supported by weak self-control, can lead to impulsive buying behaviour among consumers. Based on several explanations previously stated that financial literacy and selfcontrol are closely related to consumers' impulsive buying behaviour. With this basis, the purpose of this study is to find out how much influence the variables contained in the study. The result of this study expected to explain the phenomenon, theory, and empirical findings on financial literacy on impulsive buying behaviour mediated by self-control.

\section{Literature Review}

\section{Financial Literacy}

The OECD (Organization for Economic Co-operation and Development) INFE (International Network on Financial Education) defines financial literacy as the set of skills, information, awareness, attitude, and behavior needed to make sound financial decisions and attain personal financial well-being. Financial literacy is a measure of one's capacity to understand important financial concepts and manage personal money in terms of short-term and long-term financial planning while taking into account life's dynamism and changing economic situations (Fernandes et al., 2014). Financial literacy might also be important in households and business contexts. There are common determinants related to peoples' financial literacy levels. It can be classified based on demographic factors as well as other patterns. Age, gender, education, and professional standing, as well as income and wealth, are all drivers of demographic traits. While some recent contributions have looked at the impact of people's financial socialization on their financial literacy levels, others have looked at the impact of people's financial socialization on 
Volume 3 Issue 9 (September 2021) PP. 155-171

DOI 10.35631/AIJBES.39012

their financial literacy levels. Family, school, and work have all been recognized as potential financial socialization channels. Financial literacy can affect someone's financing decision: the less financially literate individuals are, the more likely they are to make poor financing decisions (Stolper \& Walter, 2017).

According to other studies, among participants with different incomes and higher education levels, financial knowledge at the fundamental stage has been proven. Since male respondents have a higher rate of basic financial knowledge than female respondents, survey results usually vary by gender, which is consistent with the results of the United States and other countries. In the population category, the age groups 26-35 and 36-50 have the highest levels of financial literacy and utilization of financial resources. The government is concerned about inadequate financial literacy since people frequently lack a knowledge of basic financial principles. Lack of information will have an impact on everyday decision-making, making it difficult for individuals to make the most beneficial decisions for their financial well-being. Making poor financial judgments can lead to poor financial management, which can lead to people behaving in ways that make them prone to financial crises and lose money due to financial fraud. Based on the above definition, it can be concluded that financial literacy is a person's knowledge and ability to manage their own finances in order to avoid mismanagement and to improve economic welfare.

Various financial elements must be understood in order to be considered financially literate. Financial literacy has several dimensions, according to Chen and Volpe (1998), including general financial knowledge, savings and borrowing, investment, and insurance. According to S.P Wagland and S. Taylor (2009), knowledge of finance encompasses personal finance knowledge, such as how to manage income and expenses, as well as knowing basic financial principles. Simple interest rates, compound interest, the effect of inflation, opportunity cost, time value of money, asset liquidity, and other basic financial concepts are included. According to Garman and Forgue (2010), savings is the accumulation of surplus funds achieved by intentionally consuming less than one's income. Investing, on the other hand, is saving or putting money aside so that you may work and earn more money. Putting money into assets such as stocks, bonds, and mutual funds, or purchasing real estate, is a common way for people to invest. According to Iswardono (1999) insurance is one way to protect against risks caused by uncertainty/uncertainty and the next function is for accumulation.

\section{Impulsive Buying Behavior}

Impulsive buying is unplanned shopping undertaken in response to an external stimulus, such as seeing the desired product in the store. Highly impulsive shoppers frequently pay no heed to the possible negative effects that can emerge from their actions (Choudhary, 2014). The explanation for this is that an unplanned order will easily be made at the payment counter to find that one has failed to add products to the scheduled shopping list. Along with technological developments, consumers are faced with an increasing number of choices in shopping. Not only offline stores, currently the number of e-commerce and online shops has increased drastically which can make it easier for customers to shop online. Therefore, impulsive buying behavior can be found in offline and online shopping activities. Impulsive buying has three characteristics: first, it is unexpected, and it is accompanied by a positive burst of energy. Second, the individual does not think of the consequences of the purchase. Last, it involves satisfying one's self-needs (Chein \& Lee, 2020). According to Bhakat \& Muruganantham 
Volume 3 Issue 9 (September 2021) PP. 155-171

DOI 10.35631/AIJBES.39012

(2013), impulsive buying is influenced by various factors as follows: external stimuli and store environment, internal stimuli, situational and product-related factors, and demographic and socio-cultural factors.

According to (Rook \& Fisher, 1995), there are several indicators used to measure impulsive buying behavior as follows:

1. Spontaneity or impulsive purchases occur unexpectedly or without prior intention.

2. Power compulsion, and intensity or the motivation to put aside other things and act immediately.

3. Excitement and stimulation or sudden desire to buy are often followed by emotions such as excitement, thrilling, or wildness.

4. Disregard for consequences or the desire to buy can be something that cannot be denied.

\section{Self-Control}

Self-control can be demonstrated by the ability to break terrible habits, resist temptation, and conquer first desires (Fujita et al., 2020). Self-control or the ability to suppress desires and selfregulate undesirable behavioral tendencies is a primary determinant of performance in most aspects of life (Miller et al., 2011). This is also applied in terms of financial conduct. According to Stromback et al., (2017), both solid financial behavior and financial well-being were predicted by self-control. Furthermore, self-reported financial knowledge was a better predictor of healthy financial conduct and well-being than real financial knowledge as tested by conventional literacy test questions (Lind et al., 2020).

Self-control and financial behavior, according to prior research, are concerned with financial decisions such as retirement planning and credit usage. People who have low self-control are more likely to indulge in impulsive purchases, whereas people with financial channel selfcontrol concerns are more prone to experience credit withdrawals and unanticipated long-term expenditures, leading to over-indebtedness (Achtziger et al., 2015). People's ability to save has also been proven to be impeded by their self-control. People who lack self-control are less likely to save enough for retirement. In addition to self-control, two other psychological structures that may influence financial activity and well-being are trusts and the propensity to think deliberately. People who are less optimistic are more willing to save, work longer hours, and retire later. Intuitive thinking, which is the polar opposite of deliberative thinking, has been associated to decision-making behavioral biases.

Behavior control, cognitive control, and decision-making (decisional control) are four indicators established by Averill (1973) to measure self-control. The ability of an individual to change an unpleasant situation through direct action on the environment is referred to as behavioral control. Controlling this behavior can be broken down into two parts: regulated administration and stimulus manipulation. Regulated administration is the ability of an individual to determine who controls the situation, and stimulus modification is the ability to deal with unwanted stimuli by blocking or staying away from stimuli. Cognitive control is the ability of a person to deal with negative information by explaining, assessing, or linking events in the cognitive framework in order to adapt to bad psychology or lessen stress. To put it another way, this indicator measures how a potentially harmful event is interpreted. This aspect consists of two parts: information gain and appraisal. Information gain means unpleasant Copyright (C) GLOBAL ACADEMIC EXCELLENCE (M) SDN BHD - All rights reserved 
Volume 3 Issue 9 (September 2021) PP. 155-171

DOI 10.35631/AIJBES.39012

situations, but individuals can anticipate information through various considerations. While appraisal means that individuals judge and explain the situation by observing positive information. People's ability to pick results or actions based on what they believe or recognize is known as decision control. The self-control of deciding choice works well with opportunity, freedom, and the possibility of an individual choice of various actions.

\section{Generation Z}

Based on The Pew Research Center (2019), Generation Z refers to those individuals who were born starting from 1997. This date is chosen for "different formation experiences", such as the development of new technologies and socio-economic trends, including wireless internet access and the widespread availability of high-bandwidth cellular services, and world events, including the terrorist attack on September 11. Pew declared that while they have not yet defined Generation Z endpoints, they have defined Gen Z from 1997 to 2012 for analysis in 2019. According to this definition, by 2021, the oldest group of Generation $Z$ will be 24 years old, while the youngest will be 9 years old.

Since Generation $\mathrm{Z}$ was born in the decade following the broad adoption of the World Wide Web, they are also acknowledged as "Digital Natives." World Wide Web. The character of this generation can be described as tech savvy, globally connected (in the virtual world), smarter, flexible, and tolerant of diverse cultures Baby Boomers. Since kids, Gen Z kids are raised with a highly sophisticated media and computer environment that shape them to be more expert and internet savvy than their Gen Y predecessors (Singh, 2014).

\section{Financial Literacy Previous Studies}

Table 1: Previous Studies about Financial Literacy, Impulsive Buying Behavior, and Self-Control

\begin{tabular}{|c|c|c|c|}
\hline No. & Previous Study & Variables & Findings \\
\hline 1 & $\begin{array}{l}\text { The Mediation of } \\
\text { Economic Literacy on } \\
\text { the Effect of Self } \\
\text { Control on Impulsive } \\
\text { Buying Behaviour } \\
\text { Moderated By Peers } \\
\text { (Riyanto Efendi*, } \\
\text { Setyabudi Indartono, } \\
\text { Sukidjo, 2019) }\end{array}$ & $\begin{array}{l}\text { Dependent variable: } \\
\text { Impulsive buying } \\
\text { behavior } \\
\text { Independent } \\
\text { variable: Self-control } \\
\text { Moderator variable: } \\
\text { Peers } \\
\text { Mediation variable: } \\
\text { Economic literacy }\end{array}$ & $\begin{array}{l}\text { Self- control gives a negative and } \\
\text { significant influence on impulsive } \\
\text { buying. Economic literacy } \\
\text { mediates the influence of the } \\
\text { relationship of self-control to } \\
\text { impulsive buying. Peers moderate } \\
\text { the mediation of economic literacy } \\
\text { of self-control on impulsive } \\
\text { buying. }\end{array}$ \\
\hline 2 & $\begin{array}{l}\text { Self-control, financial } \\
\text { literacy and consumer } \\
\text { over-indebtedness (John } \\
\text { Gathergood, 2012) }\end{array}$ & $\begin{array}{l}\text { Dependent variable: } \\
\text { Consumer over- } \\
\text { indebtedness } \\
\text { Independent } \\
\text { variable: Self- } \\
\text { control, financial } \\
\text { literacy }\end{array}$ & $\begin{array}{l}\text { Lack of self-control and financial } \\
\text { illiteracy are positively associated } \\
\text { with non-payment of consumer } \\
\text { credit and self- reported excessive } \\
\text { financial burdens of debt. }\end{array}$ \\
\hline
\end{tabular}


Volume 3 Issue 9 (September 2021) PP. 155-171

DOI 10.35631/AIJBES.39012

3 The Influence of Financial Literacy and Reference Group toward Consumptive Behavior Across Senior High School Students (Fikriyyah Ridhayani, Irni Rahmayani Johan, 2020)

4 Financial Literacy on Impulsive Buying Behavior Of Y Generation (Nur Aini Anisa, 2020)

5 Influence of LifeStyle and Financial Literacy to Consumptive Behavior through SelfControl of Unisnu FEB College Students Jepara (Halimatussakdiyah, 2019)

6 Financial Literacy, Materialism and Financial Behavior (Anastasia Anggarkusuma Arofah, 2018)
Dependent variable:
The level of financial literacy was
Consumptive
behavior
Independent
variable: Financial
literacy and
reference group
in the medium category, while the reference group and the level of consumptive behavior were in a low category. The regression test found a significant negative effect of financial behavior toward consumptive behavior.

Dependent variable:

Impulsive buying

behavior

Independent

variable: Financial

literacy

Dependent variable:

Consumptive

behavior

Independent

variable: lifestyle

and financial literacy

Mediation variable:

Self-control

Dependent variable:

Financial behavior

Independent

variable: Financial

literacy and

materialism.
Financial literacy has a negative and significant impact on the $\mathrm{Y}$ generation's impulsive buying of internet items. The study's conclusions are mostly confirmed by indices of financial literacy. Lifestyle, financial literacy, and self-control all affected consumer behavior. Self-control was used as a mediator to impact consumption behavior, which was influenced by lifestyle and financial literacy.

Financial literacy contributes to financial behavior positively and significantly. Materialistic attitude contributes to financial behavior negatively and significantly. Undergraduates with high financial literacy levels can manage their finances better, and those with low materialism will tend to restrain their willingness to purchase a product or service. 


\section{Conceptual Framework}

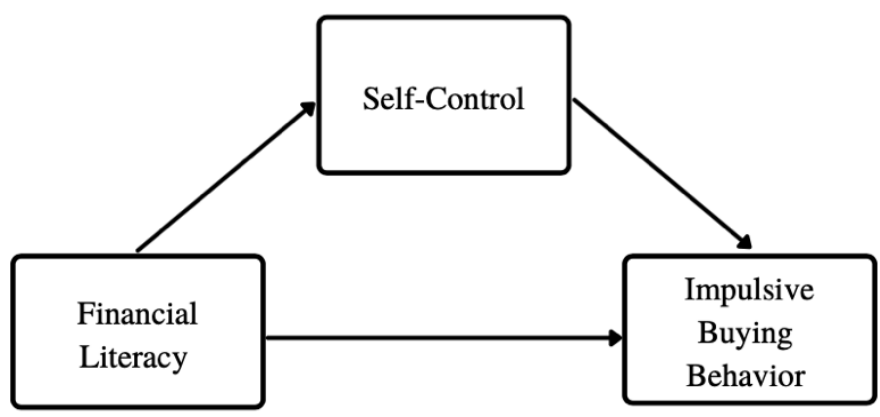

Figure 1: Conceptual Framework

H1: Financial literacy has a significant and negative influence on impulsive buying behavior $\mathrm{H} 2$ : Financial literacy has a significant and positive influence on self-control

H3: Financial literacy has an influence on impulsive buying behavior with self-control as mediating variable

\section{Methodology}

In doing this research there are six major steps needed to be conducted in order to complete the solutions. The first step conducted by the author is determine the topic and identify the problem. Author also determines the research questions, research objectives, and theoretical foundation of the topic. The next step is collecting the primary and secondary data. The primary data collected using questionnaire which indicate that researchers uses the quantitative method as the main source of the data. The questionnaire targeted Generation Z that born between 19972004 domiciled in Bandung. The sampling method the author used is convenience and purposive sampling. According to the data that was released by Badan Pusat Statistik Indonesia in 2020, the number of populations with the age ranging from 17 years old to 24 years old in Bandung is \pm 388.660 . (Adam, 2020) provides a sampling formula that will be used in this research. A 95\% confidence level and $\mathrm{P}=5 \%$ is assumed. Accordingly, with that formula, the number of samples that the author needs to obtain is 400 . Furthermore, to enrich the information to support the research, author collect data from secondary sources, such as journals, research publications, textbooks, and official websites related to the research topic. Variables used in this research are independent, dependent, and mediating variables. The independent variable is financial literacy, the dependent variable is impulsive buying behavior, and the meditation variable is self-control.

\section{Measurement}

The questionnaire is divided into four sections, demographic parts, financial literacy that consist of knowledge and ability dimension, impulsive buying behavior, and self-control. The questionnaire of this study consists of two parts, which are multiple choice and statement. The questionnaire about demographics aims to know the individual characteristics of the respondents. The questions to be asked in this section are domicile as screening question, gender, year of birth, monthly expenses, and last education. The second part is a multiplechoice questionnaire to analyze the financial literacy of the individual that was designed by 
Chen and Volpe (1998) that consists of knowledge of personal finance in general, savings and loans, investment, and insurance.

In the multiple-choice section of the questionnaire, the measuring scale employs a score or evaluation depending on the number of questions correctly answered by the respondent. The question type is in letter form, with four choices. The author scores 1 point for correct answers and 0 points for incorrect answers. As for the statement part, the measurement uses the Likert scale. The Likert scale has a scale from very positive to very negative. For the purpose of quantitative analysis, it can be reflected by each score. The Likert scale is in the form of a scale of 1 to 4 , wherein the positive statement 1 means strongly disagree, 2 disagree, 3 agree, and 4 strongly agree. Whereas in negative statements, the opposite applies.

Table 2: The Questionnaire Design of Financial Literacy Variable of Knowledge Dimension

\begin{tabular}{clcc}
\hline No. & \multicolumn{1}{c}{ Indicators } & Number & Total \\
\hline 1 & General knowledge (X1) & 1,2 & 2 \\
2 & Saving and borrowing (X2) & 3,4 & 2 \\
3 & Investment (X3) & 5,6 & 2 \\
4 & Insurance (X4) & 7,8 & 2 \\
\hline
\end{tabular}

Table 3: The Questionnaire Design of Financial Literacy Variable of Ability Dimension

\begin{tabular}{clcc}
\hline No. & \multicolumn{1}{c}{ Indicators } & Number & Total \\
\hline 1 & General knowledge (X1) & $1,2,3$ & 3 \\
2 & Saving and borrowing (X2) & $4,5^{*}, 6^{*}$ & 3 \\
3 & Investment (X3) & $7,8,9$ & 3 \\
4 & Insurance (X4) & $10,11,12$ & 3 \\
\hline
\end{tabular}

Note: $\left(^{*}\right)$ Negative statements

Table 4: The Questionnaire Design of Consumers' Impulsive Buying Behavior Variable

\begin{tabular}{clcc}
\hline No. & \multicolumn{1}{c}{ Indicators } & Number & Total \\
\hline 1 & $\begin{array}{l}\text { Spontaneity or impulsive purchases occur } \\
\text { unexpectedly (Y1) }\end{array}$ & $1^{*}, 2,3^{*}, 4$ & 4 \\
2 & $\begin{array}{l}\text { Power compulsion, and intensity or the motivation } \\
\text { to put aside other things and act immediately (Y2) }\end{array}$ & $5^{*}, 6,7,8$ & 4 \\
3 & $\begin{array}{l}\text { Excitement and stimulation or sudden desire to buy } \\
\text { (Y3) }\end{array}$ & $9,10,11,12$ & 4 \\
4 & $\begin{array}{l}\text { Disregard for consequences or the desire to buy can } \\
\text { be something that cannot be denied (Y4) }\end{array}$ & $13,14,15,16$ & 4 \\
\hline
\end{tabular}

Note: (*) Negative statements

Table 5: The Questionnaire Design of Self-Control Variable

\begin{tabular}{cllcc}
\hline No. & \multicolumn{1}{c}{ Aspects } & \multicolumn{1}{c}{ Indicators } & Number & Total \\
\hline 1 & Behavior & Regulated administration $(\mathrm{Z1})$ & $1,2,3^{*}, 4^{*}, 5$ & 5 \\
& control & Stimulus modification $(\mathrm{Z} 2)$ & $6^{*}, 7,8,9^{*}, 10$ & 5 \\
2 & Cognitive & Ability to process unwanted & $11^{*}, 12,13^{*}, 14$, & 5 \\
& control & information (Z3) & $15^{*}$ & \\
\hline
\end{tabular}


Volume 3 Issue 9 (September 2021) PP. 155-171 DOI 10.35631/AIJBES.39012

\begin{tabular}{lllc}
\hline $\begin{array}{l}\text { Decisional } \\
\text { control }\end{array}$ & $\begin{array}{l}\text { The ability people to choose results or } \\
\text { actions based on what is believed or } \\
\text { recognized. (Z4) }\end{array}$ & $\begin{array}{c}16,17^{*}, 18,19, \\
20^{*}\end{array}$ & 5 \\
\hline
\end{tabular}

Note: (*) Negative statements

Statistical approach also will be used in this study. A validity test and a reliability test are included in the test instrument. Validity is tested through Pearson correlation where the monotonous association between two variables is measured through correlation. The result of Pearson correlation is used for determining whether a research instrument, which is a closeended questionnaire, is valid or not. If correlation $r$ value $\geq r$ table with a confidence level of $95 \%$, then statements in questionnaires with related variables are significantly correlated and considered as valid. While if correlation $r$ value $\leq r$ table with a confidence level of $95 \%$, then statements in questionnaires with related variables are not significantly correlated and are considered invalid. In this study, reliability is tested based on homogeneity or internal consistency. The degree to which all of the items on a scale measure the same construct is known as reliability. Cronbach's Alpha is one of numerous homogeneity tests used by researchers. This method has been largely utilized to determine the instrument's internal consistency. Cronbach's Alpha is a number that ranges from 0 to 1 . The rule-of-thumb stated a value of Cronbach's alpha between 0.6 and 0.8 is acceptable (Wim et al, 2008).

\section{Data Analysis Method}

\section{Descriptive Statistics Analysis}

Descriptive statistics are figures that illustrate what is obtained from the survey sample by describing the data results. Descriptive statistics also assist researchers in identifying sample characteristics that may have an impact on their findings (Thompson, 2009). The minimum and maximum values, mean, and standard deviation of the study variables are included in descriptive analysis.

\section{Inferential Analysis}

The analysis of inferential statistical data was measured in this study utilizing the SmartPLS application, start with the measurement model (outer model), model structure (inner model), and hypothesis testing, all based on the formulated hypothesis. The Outer Model refers to a measurement model that connects indicators with their latent variables which are applied to assess the validity and reliability of the model. Outer model analysis can be seen from several indicators: Convergent Validty, Discriminant Validty, and Composite Reliability.

The inner model is used to analyze the causal connection (cause-effect relationship) between latent variables or variables that cannot be measured directly. Through bootstrapping prediction of the existence of causality relation can be established by obtaining a t-statistical test parameter. According to Chin (1998), the level of variation in the change in the independent variable on the dependent variable is measured by the $R^{2}$ value. The greater the $R^{2}$ score, the better the proposed research model's prediction model.

\section{Hypothesis Test}

To test whether a hypothesis is rejected or accepted, the determining indicators are t-statistical value and probability value. The t-statistic value used is 1.96 and the $\mathrm{p}$-value $\leq 5 \%(0.05)$. The Copyright $\odot$ GLOBAL ACADEMIC EXCELLENCE (M) SDN BHD - All rights reserved 
Volume 3 Issue 9 (September 2021) PP. 155-171

DOI 10.35631/AIJBES.39012

criteria for acceptance or rejection of the hypothesis are that $\mathrm{Ha}$ is accepted and $\mathrm{H} 0$ is rejected when the t-statistic $>1.96$. Whereas to determine the rejection or acceptance of the hypothesis based on probability value, the hypothesis is accepted if the $p$ value $\leq 0.05$ for $\alpha=5 \%$ (Ghozali, 2011). If the test results for the inner model are significant, it means that latent variables have a significant effect on other latent variables.

\section{Discussion and Findings}

\section{Descriptive Statistics}

Table 6: Descriptive Statistics

\begin{tabular}{cccccc}
\hline Variable. & $\mathbf{N}$ & Mean & $\begin{array}{c}\text { Std. } \\
\text { Deviation }\end{array}$ & Minimum & Maximum \\
\hline $\begin{array}{c}\text { Financial Literacy } \\
\text { Financial Literacy }\end{array}$ & 422 & 41.87 & 5.46 & 21 & 54 \\
$\begin{array}{c}\text { Knowledge Dimension } \\
\text { Financial Literacy }\end{array}$ & 422 & 5.59 & 1.67 & 1 & 8 \\
$\begin{array}{c}\text { Ability Dimension } \\
\text { Impulsive Buying }\end{array}$ & 422 & 36.28 & 4.7 & 19 & 48 \\
$\quad 422$ & 37.05 & 7.21 & 17 & 57 \\
Behavior & 422 & 56.74 & 6.08 & 25 & 75 \\
\hline
\end{tabular}

Inferential Analysis

Outer Model

Table 7: Convergent Validity

\begin{tabular}{cccc}
\hline Indicator & Financial Literacy & $\begin{array}{c}\text { Impulsive Buying } \\
\text { Behavior }\end{array}$ & $\begin{array}{c}\text { Self- } \\
\text { Control }\end{array}$ \\
\hline X1 & 0.683 & & \\
X2 & 0.810 & & \\
X3 & 0.787 & & \\
X4 & 0.457 & 0.811 & \\
Y1 & & 0.826 & \\
Y2 & & 0.708 & \\
Y3 & & 0.736 & \\
Y4 & & 0.684 \\
Z1 & & & 0.753 \\
Z2 & & & 0.753 \\
Z3 & & & 0.710 \\
Z4 & & & \\
\hline
\end{tabular}


Based on the table, it can be seen that there is 1 indicator whose value is below 0.5 , namely X4 so that the author performs repeated executions, and the final value is obtained with a loading factor $\geq 0.50$ for each indicator as shown in Figure 4.5 below:

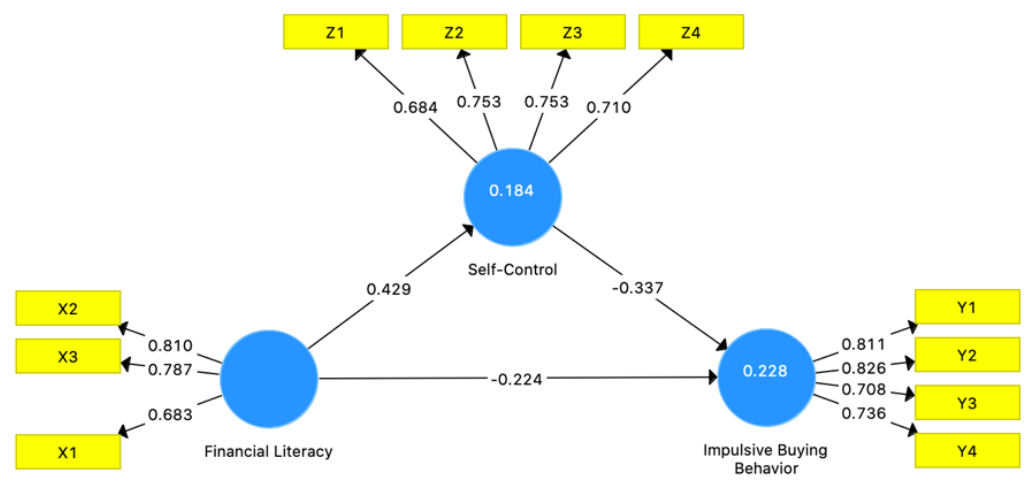

Figure 2: The Model After the Invalid Indicator is Eliminated

Table 8: AVE (Average Variance Extracted)

\begin{tabular}{cc}
\hline Variable & AVE \\
\hline Financial Literacy & 0.581 \\
Impulsive Buying Behavior & 0.596 \\
Self-Control & 0.527 \\
\hline
\end{tabular}

Based on the table above, the AVE value of each construct in the model, it is concluded that the AVE value is above 0.5. These results indicate that the data of this study have met the requirements of both convergent validities.

Table 9: Cross Loadings

\begin{tabular}{cccc}
\hline Indicator & Financial Literacy & $\begin{array}{c}\text { Impulsive Buying } \\
\text { Behavior }\end{array}$ & $\begin{array}{c}\text { Self- } \\
\text { Control }\end{array}$ \\
\hline X1 & 0.683 & -0.176 & 0.240 \\
X2 & 0.810 & -0.350 & 0.351 \\
X3 & 0.787 & -0.283 & 0.368 \\
Y1 & $-0,431$ & 0.811 & $-0,382$ \\
Y2 & $-0,248$ & 0.826 & $-0,325$ \\
Y3 & $-0,161$ & 0.708 & $-0,267$ \\
Y4 & $-0,223$ & 0.736 & $-0,339$ \\
Z1 & 0.357 & $-0,218$ & 0.684 \\
Z2 & 0.308 & $-0,287$ & 0.753 \\
Z3 & 0.243 & $-0,404$ & 0.753 \\
Z4 & 0.340 & $-0,333$ & 0.710 \\
\hline
\end{tabular}

Since the correlation value of each construct block is larger than the correlation value of other construct blocks, the indicator is declared all valid. 
Table 10: Fornell Larcker Criterion

\begin{tabular}{cccc}
\hline Indicator & Financial Literacy & $\begin{array}{c}\text { Impulsive Buying } \\
\text { Behavior }\end{array}$ & $\begin{array}{c}\text { Self- } \\
\text { Control }\end{array}$ \\
\hline Financial Literacy & 0.762 & & \\
Impulsive Buying & -0.368 & 0.772 & \\
Behavior & 0.429 & -0.433 & 0.726 \\
Self-Control & & & \\
\hline
\end{tabular}

Based on the table, it can be seen that all variables have a higher value. Financial literacy explains the variable itself compared to other variables in the same column. Financial literacy has a value of 0.762 which is higher than other variables in the same column. And the same goes for the other two variables.

Table 11: Composite Reliability

\begin{tabular}{ccc}
\hline Variable & Cronbach's Alpha & $\begin{array}{c}\text { Composite } \\
\text { Reliability }\end{array}$ \\
\hline Financial Literacy & 0.648 & 0.805 \\
Impulsive Buying & 0.778 & 0.855 \\
Behavior & 0.700 & 0.816 \\
Self-Control &
\end{tabular}

From the table above, it can be seen that stated that all variables are declared reliable because the value of composite reliability $>0.7$ and Cronbach's Alpha $>0.6$.

\section{Inner Model}

Table 12: R-Square Value

\begin{tabular}{cc}
\hline Variable & R-Square \\
\hline Impulsive Buying Behavior & 0.228 \\
Self-Control & 0.184 \\
\hline
\end{tabular}

The R-Square value for the impulsive buying behavior value obtained is 0.228 . These results indicate that $22.8 \%$ impulsive buying behavior variable can be influenced by financial literacy and self-control variables. While $77.2 \%$ is influenced by other variables outside the research. The R-Square value for the self-control variable obtained a value of 0.184 . These results indicate that $18.4 \%$ of self-control variables can be influenced by financial literacy, while $81.6 \%$ are influenced by other variables outside the research. 


\section{Hypothesis Test}

Table 13: Hypothesis Test Result

\begin{tabular}{ccccc}
\hline Hypothesis & $\begin{array}{c}\text { Original } \\
\text { Sample (O) }\end{array}$ & $\begin{array}{c}\mathbf{P} \\
\text { Values }\end{array}$ & $\begin{array}{c}\mathbf{T} \\
\text { Statistics }\end{array}$ & Information \\
\hline $\begin{array}{c}\text { Financial Literacy } \rightarrow \\
\text { Impulsive Buying } \\
\text { Behavior }\end{array}$ & -0.224 & 0.000 & 4.221 & Negative, significant \\
$\begin{array}{c}\text { Financial Literacy } \rightarrow \\
\text { Self-Control }\end{array}$ & 0.429 & 0.000 & 10.901 & Positive, significant \\
$\begin{array}{c}\text { Financial Literacy } \rightarrow \\
\text { Self-Control } \rightarrow \\
\text { Impulsive Buying } \\
\text { Behavior }\end{array}$ & -0.144 & 0.000 & 5.102 & $\begin{array}{c}\text { Mediating does } \\
\text { contribute and } \\
\text { significant }\end{array}$ \\
\hline
\end{tabular}

According to the findings of the data analysis, financial literacy has a negative and significant impact on Generation Z's impulsive buying behavior. It can be interpreted, if an individual has a low level of financial literacy, that person tends to perform a high impulsive buying behavior. Conversely, the higher a person's financial literacy, the lower the level of impulsivity. This study's finding is comparable to those of Robin and Lynda (2010), who found that materialistic people with bad money management skills are more likely to be impulsive purchasers. This is due to lack of knowledge and ability to manage financial expenditure.

This study also shows the path analysis test results with a positive coefficient of 0.429 , which means that financial literacy has a direct or proportional effect to self-control. With a significant value of $0.000<0.05$, means that financial literacy affects significantly and positively towards self-control. Mischel (2014) put forward the viewpoints in the theoretical research that reinforce the results of this research, that is, one of the factors that affect individuals is emotional control. The ability to suppress emotional activity is what emotional control is defined as. Only those who are able to regulate their emotions are able to control themselves. Self-control is linked to financial management, which is also known as financial literacy. People with financial knowledge and ability can certainly control their own consumption. Therefore, students with good financial knowledge will use their money carefully so that they can control themselves and avoid deficits. Moreover, according to Cobb- Clark, Dahmann, and Kamhöfe (2019), individuals with higher self-control are more likely to stick to long-term goals, including financial ones.

The parameter coefficient of the impact of financial literacy on self-control consumption behavior is 0.000 or lower than 0.05 , and the parameter coefficient is -0.144 , according to the analysis result based on hypothesis 3 . This suggests that, through self-control, financial literacy has a negative and significant impact on consumer impulsive buying behavior. In addition, based on the path analysis test result, self-control has a significant mediating role. When it comes to consumption, individuals with a high level of financial literacy will first identify what the existing expenditure items are and how much nominal they must spend for each expenditure item. So that way, individuals can better know their financial condition and goals. After Copyright $@$ GLOBAL ACADEMIC EXCELLENCE (M) SDN BHD - All rights reserved 
Volume 3 Issue 9 (September 2021) PP. 155-171

DOI 10.35631/AIJBES.39012

knowing the existing spending budget, an individual will use the budget as a benchmark for consumption. So that individuals tend to be more able to sort out what needs must be met first. In other words, individuals become more able to control themselves and are not easily tempted to make unnecessary expenses because it will make the budget plan that has been made deviated.

\section{Conclusions}

This study aims to identify the relationship between financial literacy on Generation $\mathrm{Z}$ consumers impulsive buying behavior mediated by self-control. Path analysis using Structural Equation Modeling (SEM) Smart Partial Least Squares (PLS) was used to determine the relationship between financial literacy, impulsive buying behavior, and self-control in this study. The results of the coefficient path showed that financial literacy had a negative effect on impulsive buying behavior, with an original sample value of -0.224 and P-values of 0.000 . This means that financial literacy has a negative impact on impulsive purchase behavior by $22,44 \%$.

Furthermore, it is found that financial literacy positively and significantly affect self-control. According to the coefficient path result which show the original value of 0.429 and P-values of 0.000 , meaning that financial literacy has a positive effect on self-control by $42.9 \%$. Lastly, financial literacy through self-control has an effect on impulsive buying behavior. The coefficient path shows the original value of -0.144 and the P-values of 0.000 . This implies that self-control have a partial mediating role and in other words, financial literacy negatively and significantly affects impulsive buying behavior through self-control by $14.4 \%$.

\section{References}

Achtziger, Anja; Hubert, Marco; Kenning, Peter; Raab, Gerhard; Reisch, Lucia (2015). Debt out of control: The links between self-control, compulsive buying, and real debts. Journal of Economic Psychology, 49(), 141-149. doi:10.1016/j.joep.2015.04.003

Adam, A. M. (2020). Sample Size Determination in Survey Research. Journal of Scientific Research and Reports, 26(5), 90-97. https://doi.org/10.9734/jsrr/2020/v26i530263

Atkinson, A. (n.d.). Measuring Financial Literacy: Results of the OECD / International Network on Financial Education (INFE) Pilot Study. Measuring Financial LiteracyResults of the OECD / International Network on Financial Education (INFE) Pilot Study. https://doi.org/10.1787/5k9csfs90fr4-en

Averill, James R. (1973). Personal control over aversive stimuli and its relationship to stress. Psychological Bulletin, 80(4), 286-303. doi:10.1037/h0034845

Bhakat, R. S., \& Muruganantham, G. (2013). A Review of Impulse Buying Behavior. International Journal of Marketing Studies, 5(3). https://doi.org/10.5539/ijms.v5n3p149

Budiansyah, Arif. (2020, January 15). Alasan GoPay, DANA, \& LinkAja Cs Kian Digandrungi di RI. CNBC Indonesia. https://www.cnbcindonesia.com/tech/20200115122416-37130148/alasan-gopay-dana-linkaja-cs-kian-digandrungi-di-ri

Choudhary, S. (2014). Study of Impulse Buying Behavior of Consumers. International Journal of Advance Research in Computer Science and Management Studies, 2(9), 1-4.

Chein, T. S., \& Lee, C. J. (2020). Factors Affecting Impulsive Buying Behaviour - Evidence from Malaysia. 12(2), 1-15.

Chen, H. \& Volpe, R.P. (1998). An Analysis of Personal Financial Literacy Among College Students. Financial Services Review, 7 (2), 107-128. 
Volume 3 Issue 9 (September 2021) PP. 155-171

DOI 10.35631/AIJBES.39012

Chin, W. W. (1998). The partial least squares approach for structural equation modeling. Modern Methods for Business Research, January 1998, 295-336.

Cobb-Clark, D. A., Dahmann, S. C., Kamhöfe, D. A., \& Schildberg-Hörisch, H. (2019). SelfControl: Determinants, Life Outcomes and Intergenerational Implications.Bonn, Germany: IZA Institute of Labor Economics.

Dimock, Michael. (2019, January 17). "Defining generations: Where Millennials end and Generation Z begin". Retrieved June 30, 2021. From https://www.pewresearch.org/fact-tank/2019/01/17/where-millennials-end-andgeneration-z-begins/

Efendi, R., Indartono, S., \& Sukidjo, S. (2019). The Mediation of Economic Literacy on the Effect of Self Control on Impulsive Buying Behaviour Moderated By Peers. International Journal of Economics and Financial Issues, 9(3), 98-104. https://doi.org/10.32479/ijefi.7738

Fernandes, D., Lynch, J. G., \& Netemeyer, R. G. (2014). Financial literacy, financial education, and downstream financial behaviors. Management Science, 60(8), 1861-1883. https://doi.org/10.1287/mnsc.2013.1849

Fujita, Kentaro; Orvell, Ariana; Kross, Ethan (2020). Smarter, Not Harder: A Toolbox Approach to Enhancing Self-Control. Policy Insights from the Behavioral and Brain Sciences, 7(2), 149-156.doi:10.1177/2372732220941242

Garman, E. Thomas \& Forgue, Raymond E. (2010). Personal Finance International Edition. Canada: South Western Cengage Learning

Ghozali, I. (2011). Aplikasi Analisis Multivariate dengan Program IBM SPSS 19 (Edisi 5) . Semarang: Universitas Diponegoro.

Iswardono. (1999). Uang dan Bank . Yogyakarta: BPFE UGM.

Lind, Therese; Ahmed, Ali; Skagerlund, Kenny; Stromback, Camilla; Vastfjall, Daniel; Tinghog, Gustav (2020). Competence, Confidence, and Gender: The Role of Objective and Subjective Financial Knowledge in Household Finance. Journal of Family and Economic Issues, (), -.doi:10.1007/s10834-020-09678-9

Mischel, W. (2014). The Marshmallow Test: Mastering Self-control (4rd ed). New York: Little, Brown, and Company.

OJK. (2019). Survei Nasional Literasi dan Inklusi Keuangan 2019. Survey Report, 1-26. www.ojk.go.id

Ridhayani, F., \& Johan, I. R. (2020). The Influence of Financial Literacy and Reference Group toward Consumptive Behavior Across Senior High School Students. Journal of Consumer Sciences, 5(1), 29-45. https://doi.org/10.29244/jcs.5.1.29-45

Robin Pentecost; Lynda Andrews (2010). Fashion retailing and the bottom line: The effects of generational cohorts, gender, fashion fanship, attitudes and impulse buying on fashion expenditure. , 17(1), 0-52. doi:10.1016/j.jretconser.2009.09.003

Rook, Dennis W.; Fisher, Robert J. (1995). Normative Influences on Impulsive Buying Behavior. Journal of Consumer Research, 22(3), 305-. doi:10.1086/209452

Singh, A. (2014). Challenges and Issues of Generation Z. IOSR Journal of Business and Management, 16(7), 59-63. https://doi.org/10.9790/487x-16715963

Stolper, O. A., \& Walter, A. (2017). Financial literacy, financial advice, and financial behavior. Journal of Business Economics, 87(5), 581-643. https://doi.org/10.1007/s11573-0170853-9 
Volume 3 Issue 9 (September 2021) PP. 155-171

DOI 10.35631/AIJBES.39012

Stromback, C., et. al. (2017). Does self-control predict financial behavior and financial wellbeing?. Journal of Behavioral and Experimental Finance. http://dx.doi.org/10.1016/j.jbef.2017.04.002

Thompson, C. B. (2009). Descriptive Data Analysis. Air Medical Journal, 28(2), 56-59. https://doi.org/10.1016/j.amj.2008.12.001

Wagland, S. P. and Taylor, S., When it comes to financial literacy, is gender really an issue?, Australasian Accounting, Business and Finance Journal, 3(1), 2009.

Wim J., Katrien W., Patrick D. P., and Patrick V. K., (2008). Marketing Research with SPSS 